\title{
Krakovská konference o času v ruské kultuře
}

Katedra antropologie ruské kultury Fakulty mezinárodních a politických studií Jagellonské univerzity v Krakově uspořádala ve dnech 20.-21. září 2018 mezinárodní konferenci orientovanou na studium role a zobrazení času v ruské kultuře (oficiální název konference zněl Czas v kulturze rosyjskiej), jejímž hlavním organizátorem byl prof. A. Dudek.

Téma přilákalo pět desítek badatelů z Polska, Madarska, Ukrajiny, Ruska, Česka, Francie, Litvy, USA a Kazachstánu, kteří téma pojali nejrůznějším způsobem, takže čas byl nahlížen z mnoha zorných úhlů. Pro některé z účastníků byl čas kategorií jazyka, např. jako součást frazeologických obratů, anebo jako jistý úsek vývoje některé ze sfér ruského jazyka (např. v pojmenování obchodů a firem), pro další pak byl předmětem jejich úvah mytologický čas. Řada příspěvků směřovala k dokumentaci konkrétních úseků vývoje ruské společnosti a kultury s výraznějším zájmem o dobu před revolucí roku 1917 či těsně po ní, anebo o dynamiku dění v ruské společnosti v současné vývojové etapě. Poměrně značné množství příspěvků si všímalo zobrazení času v ruské literatuře, a to at’ už jako subjektivizovaného nebo „objektivního“ času v různých literárních žánrech (cestopis/travelog, lyrická poezie, román), času jako „podmínky pro dění“ či rozporu mezi konkrétně vnímaným časem a „bezčasím“, prrípadně pak jako snahy čas „uchopit“, zastavit, využít v jeho kontinuálním či diskontinuálním plynutí. Protiklad pojetí „neantropologizovaného“ času (chronos) a času v jeho podobě „antropologizované“ (kairos) se tak přímo či nepřímo objevoval ve většině příspěvků, aniž by však byla tato okolnost nějak výrazněji tematizována. V pestrém multidiciplinárním konferenčním programu vznikala př́iležitost pro věcné diskuse, které byly využívány pro upřesňování pojmů, faktů i pro konfrontaci př́istupu k tématu času z pohledu různých oblastí humanitních věd. V této konfrontaci poněkud chyběl právě pohled filozofie - ten se v náznacích objevil až v úplném závěru konference ve vystoupení ředitele pořádajícího pracoviště prof. J. Diece.

Časové limity pro jednotlivé př́íspěvky byly relativně omezené, plné znění (a tedy i plný přínos) zazněvších vystoupení bude možné hodnotit spíše až po vydání konferenčního sborníku. I tak už lze konstatovat, že právě multidisciplinárnost konference byla dynamizujícím prvkem a umožnila vícevrstevný pohled na rozvoj ruské kultury i na její vztahování se k základní kategorii, jež všechny příspěvky spojovala, tedy $\mathrm{k}$ času. 